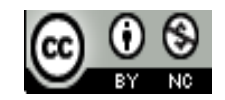

Journal of Education, Teaching, and Learning is licensed under

A Creative Commons Attribution-Non Commercial 4.0 International License.

\title{
Social VAlUES REFLECTED IN "BATU DARA MUNING" AN ORAL LiTERATURE OF DAYAK KENINJAL TRIBE
}

\author{
Martono \\ Universitas Tanjungpura, Pontianak, Indonesia \\ E-mail: martono_fkipuntan@yahoo.co.id
}

\begin{abstract}
Oral literature has an important function in life because it can reflect people's lives and instill a sense of love for their own culture. Oral literature is a cultural heritage of the region passed down from generation to generation which is narrated from mouth to mouth and has a noble value. The noble value contained in oral literature reflects the local culture of the tribe. Certain noble values must be continuously preserved and implemented in the life of society and state. The noble value as a form of character education, such as social values. Therefore, positive social values must be maintained. The social values as many ancestral riches are also found in Dayak Keninjal oral literature titled Batu Dara Muning. The social value that can be found in oral literature entitled Batu Dara Muning is the value of a mother's love for a child, obedient to parents, forbidden marriage, obedience to customs. To analyze oral literature Batu Dara Muning used approach of sociology of literature. The reason literature is a mirror of the lives of the people who own the story. Stories or events expressed in oral literature are sourced from events in society with the narrator's imagination. The character used in oral literature is not the name of the character in his tribe, but the name made by the narrator.
\end{abstract}

Keywords: Oral Literature; Social Values; Sociological Approach to Literature

\section{INTRODUCTION}

Oral literature is a form of a statement of community life in the past that is passed down from generation to generation to the oral supporters. In general oral literature grows and develops in rural communities far from urban. This does not mean, however, that oral literature does not exist in a society that already recognizes writing, but its role is not as great in a society as it has not been or has been familiar with writing (Danandjaya, 1991; Tololi, 1990).

In oral literature, there is a very useful value to the people. There are noble values that can be drawn from oral literature. The noble values conveyed by the narrator consist of conceptions that live in the minds of most citizens, about the things they should consider as valuable in life. Therefore, a cultural value system usually serves as the ultimate guide to human behavior. Cultural values that exist in society greatly affect one's attitude. Therefore, the noble value contained in oral literature must be continuously preserved and implemented in the life of society and state (Hutomo, 1991).
According to Teeuw (1994: 22), there is a direct connection between genius in traditional culture and its strong sense of collectivity, in which members of society together have information relevant to their survival, either as individuals or as a whole. In this kind of society, storytellers have an important role, because in the story that he staged or told stored information and value systems are directly relevant to the community concerned.

Oral Literature Dayak Keninjal has been studied from its structural aspect (Martono, 2010). One of the oral literature is Batu Dara Muning. In the story of Batu Dara Muning there are values that can be taken. They are like social values. Social value is the values that exist in society. Social value must be obeyed by society. Social values become important to know and are implemented by society. These values become the wealth of society. The social values reflected in the oral literature of the Dayak tribe of Keninjal until now become the foundation when society lives in society. It becomes interesting to know the form of social values reflected in Batu Dara Muning's story. 
To analyze the form of social values reflected in the story of Batu Dara Muning using the approach of sociology of literature. By using this approach is expected to find the form of social values. The approach of literary sociology understands literature as a mirror of its environment (Damono, 1984).

\section{LITERATURE REVIEW}

Social Values

A. Compassion

Compassion is defined by love, affection. In this affection, consciously or unconsciously, each of them is responsible for responsibility, sacrifice, honesty, mutual trust, mutual understanding, mutual openness, so that both are unified and whole (Prasetya et al., 1998: 52; Widagdho et al. , 1999: 46). Loosely, affection can be defined as feelings of affection, feelings of love or feelings of love to someone.

The concept of affection by the Dayak tribe of Keninjal is applied in the family, and in social interaction. The love of a father or mother is not oriented to the sex of the child, son or daughter alike. The affection they embody by educating their children to work hard not spoil the child. Boys are required to work in "bebahat" forests, graze sap, search for forest products, hunt, while girls are taught to make webbing such as mats, baskets, temansai.

In addition to the love in the family, affection should also be given to fellow human beings. A person's love affects the attitude of always respecting, and helping others. The form of affection in the community by Dayak tribe Keninjal is helping each other neighbors when setting up homes, throw a party. The affection that sustains the harmonious life is reproduced in the oral literature of Dayak Keninjal. B. Obedient to Parents

The existence of children in the world because of both parents. Tampa they a child will not exist. How great the struggle and sacrifice of our parents during childbirth and educate us. They are willing to sacrifice their lives and property for the sake of their children. They will not willingly sick and starving children. It is a form of the affection of both parents to their children.

What is the attitude of a child to both parents? A child is obliged to serve his parents. The dutiful obligation of a child to his two master's men can be seen in the life of the Dayak tribe community of Keninjal. In his oral literature can also be seen a dutiful form of a child to his parents.

\section{Obedient to Customs}

The custom is a rule that regulates social life in the society. Customs is an agreement that must be implemented in community groups. There are rules that must be agreed upon by certain groups of people. Tata life is like an ethical, how to mingle in a community group conducted by hereditary .. Customs not only regulate human relationships with humans. The custom also governs human relationships with the natural surroundings (Koentjaraningrat, 1992; Pritchard in Ludjit, 1984)

In the life of the community Dayak tribe, Keninjal highly upholds the customs. The customs are used as the basis for the society. If there are people who violate the customs will be punished. Customary law is decided by traditional chairman and traditional leader. If it has been decided against the people who violate the custom must obey it. One of the forms of custom is the marriage of blood. In the story of Batu Dara Muning told the marriage of a mother to her son (Martono, 2010).

\section{METHODOLOGY}

This research is included in qualitative research. The data source is Batu Dara Muning's documented story. Data collection techniques document studies. To analyze using a literary sociology approach that focuses on literary texts (Damono, 1984, Junus, 1986).

\section{RESULTS AND DISCUSSION}

\section{Social Value in Batu Dara Muning's story}

The social values reflected in the Batu Dara Muning story are the affection of the parents to the child, the child's devotion to the parents, obedience to the customs. The social values will be discussed below.

\section{A. Parents love to Children}

The love and affection of a mother to her child is undeniable. The love and affection of a mother to her child of all time. Mother will be willing to suffer the origin of her children happy. In the life of Dayak tribe, Keninjal love and affection are very visible. A mother's love and affection to the child can be seen in the following quotation.

Dara Muning's son was named Bujang Munang. The child was cared for with affection. The child also thrives, healthy, clever, and deft. Bangkang Munang is always the smartest and always win when playing with his friends.

A mother's love is very important for her children. Compassion can be seen from the figure of "Dara Muning" to his son. The proof of Dara Muning's affection in the quote is with the word ... loving. He is very fond of Bujang Munang. Even though he was raising his son alone. The compassion given by Dara Muning resulted in a child who thrived, healthy, and deftly.

\section{B. Obedient to Parents}

A child must obey both parents. The form of obedience is the love and affection of children to their parents. The affection that parents have given to 
children will not be able to get avenged. In the story of Batu Dara Muning can be found obedience a child to his parents. Check out the following quote.

Dara Muning's body feels pain because it works a lot. Dara Muning will take his fallen spyglass. Suddenly came the sound of his son playing with his friends. Tampa moved from his seat, he exclaimed: "Munang get the mother's binoculars". Bujang Munang who was playing because he heard his mother's voice immediately got up and took binoculars that fell under the house...

Based on the quote proved how obedient Bujang Munang to his mother. Usually, a child will play cool to forget the time and learn. But not for Bujang Munang. Bangkang Munang who was cool to play immediately following his mother's orders. He followed his mother's orders to take the falling binoculars. It can be seen from the phrase 'take binoculars'.

\section{Obedience to Customs}

Dayak Keninjal tribe has customs. Customs are ruled that have been agreed upon by the Dayak Keninjal community. Customs are highly respected by the Dayak Keninjal community. In the story of Batu Dara Muning, there is a value that proves how the people of Dayak tribe of Keninjal are very obedient to the customs. Dara Muning's marriage with Bujang Munang (same-birth mother's marriage). This marriage has violated the customs of Dayak Keninjal tribe. Their marriage is a bloody crime and cursed by the Gods. They must separate and pay the custom. This can be seen in the following quotation.

They were told to pay a ransom to the Gods in order not to be angry. The ransom was to erect a poja, a high platform to offer sacrifices in the form of a variety of foods, animal flesh and so on. The animals were slaughtered with spells and witnessed by specially invited people... Bujang Munang made a ransom that made the poja...

The neighbors and their friends advised that the marriage is canceled, do not continue because of obeying customs. Bujang Munang Compliance is proven by paying custom by making poja. Poja is made as a form to atone for the sins they have committed. They also must offer sacrifices in the form of food, meat, and others. Unfortunately for Bujang Munang, perhaps because of lack of caution or the will of the Gods, when splitting wood, instantly it is not with his ax swinging ax injured his cock until his cock blood out a lot.

\section{CONCLUSION}

Oral literature is a cultural heritage of the region passed down from generation to generation which is narrated from mouth to mouth and has a noble value. The noble value contained in oral literature reflects the local culture of a tribe. The story of the area living in the community is spoken because there are noble values that must be maintained and implemented. The regional story entitled Dara Muning has valuable social values. The social values reflected in the story are very clear. Social value is the parental affection to the child, obedience of the child to the parents, and obedient to customs. The form of social values is still maintained in the community of Dayak Keninjal tribe.

\section{REFERENCES}

Damono, Sapardi Djoko. 1984. Sosiologi Sastra. Jakarta. Pusat Pembinaan dan Pengembangan Bahasa.

Danandjaya, James. 1991. Foklor Indonesia. Jakarta. Pustaka Utama Grafiti.

Fowler, James W. Tanpa Tahun. Teori Perkembangan Kepercayaan. Terjemahan Agus Cremes. 1995. Yogyakarta. Kanisius.

Hutomo, Suripan Sadi. 1991. Mutiara yang Terlupakan. Pengantar Studi Sastra Lisan. Jawa Timur: HISKI.

Junus, Umar. 1986. Sosiologi Sastra, Persoalan, Teori dan Metode. Kualalumpur. Dewan Bahasa dan Pustaka.

Koentjaraningrat. 1992. Beberapa pokok Antropologi Sosial. Jakarta. Dian Rakyat.

Martono. 2010. Sikap Hidup Orang Dayak Keninjal. Pontianak: STAIN Press.

Prasetya, Djoko Tri. 1998. Ilmu Budaya Dasar. Jakarta. Rineka Cipta.

Pritchard. E.E. Evans. Tanpa Tahun. Teori-teori Tentang Agama Primitif. Terjemahan H. A. Ludjit. 1984. Jakarta. PLP2M

Teeuw, A. 1994. Indonesia antara Kelisanan dan Keberaksaraan. Jakarta. Dunia Pustaka Jaya.

Tololi, Nani. 1990. Tanggomo, Salah Satu Ragam Sastra Lisan Gorontalo. Jakarta. Intermasa

Widagdho, Djoko. dkk.1999. Ilmu Budaya Dasar. Jakarta: Bumi Aksara. 